\title{
Asuhan Keperawatan Jiwa Pada Tn. P Dengan Gangguan Sensori \\ Persepsi : Halusinasi Di Jalan Setia Luhur Gang Raya
}

\author{
Swasti Telaumbanua \\ $\underline{\text { swastidelau@gmail.com }}$
}

\section{BAB I \\ PENDAHULUAN}

\subsection{Latar Belakang}

Skizofrenia merupakan kondisi psikotik yang berpengaruh terhadap area fungsi individu termasuk berpikir, berkomunikasi, menerima, menafsirkan kenyataan, merasakan dan menunjukkan emosi serta penyakit kronis yag ditandai dengan pikiran kacau, delusi, halusinasi, dan perilaku aneh (Rhoads, 2011). Gejala skizofrenia dapat mengalami perubahan semakin membaik atau semakin memburuk dalam kurun waktu tertentu, hal tersebut berdampak dengan hubungan pasien dengan diirnya sendiri serta orang yang dekat dengan penderita (Pardede, Keliat \& Wardani, 2013)

Halusinasi merupakan keadaan seseorang mengalami perubahan dalam pola dan jumlah stimulasi yang diprakarsai secara internal atau eksternal disekitar dengan pengurangan, berlebihan, distorsi, atau kelainan berespon terhadap setiap stimulus (Pardede, Keliat, \& Yulia, 2015). Halusinasi pendengaran paling sering terjadi ketika klien mendengar suara-suara, suara tersebut dianggap terpisah dari pikiran klien sendiri. Isi suara-suara tersebut mengancam dan menghina, sering 2 kali suara tersebut memerintah klien untuk melakukan tindakan yang akan melukai klien atau orang lain (Nyumirah, 2013). 
Merawat pasien skizofrenia dengan masalah halusinasi dibutuhkan pengetahuan, keterampilan dan kesabaran serta dibutuhkan waktu yang lama akibat kronisnya penyakit ini. Anggota keluarga yang bersama pasien skizofrenia menghabiskan lebih banyak waktu di rumah untuk merawat yang sakit dari pada memperhatikan dan mengurusi dirinya. Kemampuan dalam merawat pasien skizoprenia merupakan keterampilan yang harus praktis sehingga membantu keluarga dengan kondisi tertentu dalam pencapaian kehidupan yang lebih mandiri dan menyenangkan (Patricia et al, 2019).

Penatalaksaan halusinasi yaitu membantu mengenali halusinasi dengan cara melakukan diskusi dengan klien tentang halusinasinya (apa yang didengar/dilihat), waktu terjadi halusinasi, frekuensi halusinasi, situasi yang menyebabkan halusinasi muncul dan respon klien saat halusinasi muncul, untuk dapat mengontrol halusinasi klien dapat mengendalikan halusinasinya ketika halusinasi kambuh, penerapan ini dapat menjadi jadwal kegiatan sehari-hari yang dapat diterapkan klien yang bertujuan untuk mengurangi masalah halusinasi yang dialami klien dengan gangguan persepsi sensori (halusinasi dengar) (Keliat dkk, 2012).

Survei awal pada pembuatan askep pada skizofrenia ini dilakukan di Jalan Setia Luhur Gang Raya, Kec. Medan Helvetia yang ditemukan pasien gangguan sensori persepsi : halusinasi atas nama inisial Tn.P yang menjadi subjek didalam pembuatan askep ini berjumlah 1 orang dengan pasien Halusinasi pendengaran atas nama inisial Tn.P. penyebab Tn.P dijadikan sebagai subjek dikarekan pasien belum bisa mengatasi halusinasi pendengaran selain minum air putih dan minum obat.

1.2 Rumusan Masalah

Berdasarkan masalah yang telah di paparkan pada latar belakang maka rumusan masalah dalam askep ini yaitu Asuhan Keperawatan Halusinasi Pendengaran Tn.P di Kec. Medan Helvetia

\subsection{Tujuan Penulisan}




\subsubsection{Tujuan Umum}

Mahasiswa mampu memberikan asuhan keperawatan secara holistik dan komprehensif kepada Tn.P dengan gangguan persepsi sensori : halusinasi pendengaran.

\subsubsection{Tujuan Khusus}

1. Mahasiswa mampu mengetahui defenisi, tanda dan gejala, faktor penyebab, mekanisme koping penatalaksanaan pada pasien dengan Halusinasi 2. Mahasiswa

2. mampu melakukan pengkajian pada pasien dengan Halusinasi.

3. Mahasiswa mampu menegakkan diagnosa atau masalah keperawatan pada Ny.S dengan Halusinasi

4. Mahasiswa mampu menetapkan intervensi keperawatan pada diagnosa Halusinasi.

5. Mahasiswa mampu melakukan tindakan keperawatan Halusinasi

6. Mahasiswa mampu megevaluasi sebagai tolak ukur guna menerapkan asuhan keperawatan dengan Halusinasi.

\subsubsection{Manfaat}

1. Pasien Diharapkan tindakan yang telah di ajakarkan dapat di terapkan secara mandiri untuk mengontrol halusinasi dan untuk mendukung kelangsungan kesehatan pasien

2. Keluarga Diharapkan keluarga dapat memberikan dukungan moral, emosional dan spiritual serta membantu dalam menerapkan asuhan keperawatan jiwa kepada pasien dengan masalah ganggan sensori persepsi : halusinasi

3. Institusi Pendidikan Bagi institusi pendidikan diharapkan untuk menjadi acuan dalam dalam melakukan kegiatan kemahasiswaan dalam bidang keperawatan jiwa. 


\section{BAB II \\ TINJAUAN TEORI}

\subsection{Konsep Dasar Halusinasi Pendengaran}

\subsubsection{Pengertian}

Halusinasi merupakan salah satu gejala yang sering ditemukan pada klien dengan gangguan jiwa.halusinasi identik dengan skizofrenia. Seluruh klien skizofrenia diantaranya mengalami halusinasi. Halusinasi merupakan gangguan persepsi dimana klien mempersepsikan sesuatu yang banyak terjadi. Suatu penerapan panca indra tanpa ada rangsangan dari luar. Suatu penghayatan yang dialami seperti suatu persepsi melalui panca indra tanpa stimulus eksternal ; persepsi palsu. Berbeda dengan ilusi dimana klien mengalami persepsi pada halusinasi yang terjadi tanpa adanya stimulus yang terjadi. Stimulus internal dipersepsikan sebagai suatu yang nyata ada oleh klien, (Muhith,2015).

\subsubsection{Klasifikasi Halusinasi}

Menurut Yusuf (2015) klasifikasi halusinasi dibagi menjadi 5 yaitu :

\begin{tabular}{|c|l|rr|r|}
\hline No & \multicolumn{1}{|c|}{$\begin{array}{c}\text { Jenis } \\
\text { halusinasi }\end{array}$} & \multicolumn{2}{|c|}{ Data Objektif } & Data Subjektif \\
\hline 1 & Halusinasi & 1. Bicara atau tertawa & 1. Mendengar suara atau \\
& Pendengaran & sendiri tanpa lawan & kegaduhan \\
& & bicara & & 2. Mendengar suara yang \\
\hline
\end{tabular}




\begin{tabular}{|c|c|c|c|}
\hline & & $\begin{array}{l}\text { 2. Marah-marah tanpa } \\
\text { sebab mencondongkan } \\
\text { telinga ke arah tertentu } \\
\text { 3. Menutup telinga }\end{array}$ & $\begin{array}{l}\text { mengajak bercakap- } \\
\text { cakap } \\
\text { 3. Mendengar suara yang } \\
\text { menyuruh melakukan } \\
\text { sesuatu yang berbahaya }\end{array}$ \\
\hline 2 & $\begin{array}{l}\text { Halusinasi } \\
\text { penglihatan }\end{array}$ & $\begin{array}{l}\text { 1. Menunjuk-nunjuk ke } \\
\text { arah tertentu } \\
\text { 2. Ketakutan pada objek } \\
\text { yang tidak jelas }\end{array}$ & $\begin{array}{l}\text { 1. Melihat bayangan, sinar, } \\
\text { bentuk geometris, bentuk } \\
\text { kartun, melihat hantu } \\
\text { atau monster }\end{array}$ \\
\hline 3 & $\begin{array}{l}\text { Halusinasi } \\
\text { penciuman }\end{array}$ & $\begin{array}{l}\text { 1. Menghindu seperti } \\
\text { sedang membaui bau- } \\
\text { bauan tertentu } \\
\text { 2. Menutup hidung }\end{array}$ & $\begin{array}{l}\text { 1. Membaui bau-bauan } \\
\text { seperti bau darah, urine, } \\
\text { feses, } \\
\text { 2. kadang-kadang bau itu } \\
\text { menyenangkan }\end{array}$ \\
\hline 4 & $\begin{array}{l}\text { Halusinasi } \\
\text { pengecepan }\end{array}$ & $\begin{array}{l}\text { 1. Sering meludah } \\
\text { 2. Muntah }\end{array}$ & $\begin{array}{l}\text { 1. Merasakan rasa seperti } \\
\text { darah, urine, feses }\end{array}$ \\
\hline 5 & $\begin{array}{l}\text { Halusinasi } \\
\text { perabaan }\end{array}$ & $\begin{array}{l}\text { Menggaruk-garuk } \\
\text { permukaan kulit }\end{array}$ & $\begin{array}{l}\text { 1. Mengatakan ada } \\
\text { serangga di permukaan } \\
\text { kulit } \\
\text { 2. Merasa seperti tersengat } \\
\text { listrik }\end{array}$ \\
\hline
\end{tabular}

\subsubsection{Tanda dan Gejala}

Tanda dan gejala halusinasi dinilai dari hasil observasi terhadap pasien serta ungkapan pasien. Menurut (Keliat, 2019), tanda dan gejala pasein halusinasi adalah sebagai berikut :

\section{Data Objektif}

1. Bicara atau tertawa sendiri

2. Marah-marah tanpa sebab

3. Memalingkan muka ke arah telinga seperti mendengar sesuatu 
4. Menutup telinga

5. Menunjuk ke arah tertentu

6. Ketakutan pada sesuatu yang tidak jelas

7. Mencium sesuatu seperti sedang membaui bau-bauan tertentu

8. Menutup hidung

9. Sering meludah

10. Muntah

11. Menggaruk-garuk permukaan kulit

Data Subjektif : Pasien mengatakan

1. Mendengar suara-suara atau kegaduhan

2. Mendengar suara yang mengajak bercakap-cakap

3. Mendengar suara menyuruh melakukan sesuatu yang berbahaya

4. Melihat bayangan, sinar, bentuk geometris, bentuk kartun, melihat hantu atau monster

5. Mencium bau-bauan seperti bau darah, urin, feses, kadang-kadang bau menyenangkan

6. Merasakan rasa seperti darah, urin atau feses

7. Merasa takut atau senang dengan halusinasinya

8. Mengatakan sering mendengar sesuatu pada waktu tertentu saaat sedang sendirian

9. Mengatakan sering mengikuti isi perintah halusinasi

\subsubsection{Etiologi}

\section{Faktor Predisposisi}

Faktor predisposisi sebagai faktor risiko yang menjadi sumber terjadinya stres yang mempengaruhi tipe dan sumber dari individu untuk menghadapi stres baik yang biologis, psikososial dan sosial kultural. Membedakan stressor predisposisi menjadi tiga, meliputi biologis, psikologis dan sosial budaya. Stressor predisposisi ini kejadiannya telah berlalu (Stuart, 2013). Penjelasan secara rinci tentang ketiga stressor predisposisi tersebut sebagai berikutmenurut (Yosep 2016) : 


\section{a. Biologis}

Faktor biologis terkait dengan adanya neuropatologi dan ketidakseimbangan dari neurotransmiternya. Dampak yang dapat dinilai sebagai manifestasi adanya gangguan adalah perilaku maladaptif klien . Secara biologi riset neurobiologikal memfokuskan pada tiga area otak yang dipercaya dapat melibatkan klien mengalami halusinasi yaitu sistem limbik, lobus frontalis dan hypothalamus.

Pada klien dengan halusinasi diperkirakan mengalami kerusakan pada sistem limbic dan lobus frontal yang berperan dalam pengendalian atau pengontrolan perilaku, kerusakan pada hipotalamus yang berperan dalam pengaturan mood dan motivasi. Kondisi kerusakan ini mengakibatkan klien halusinasi tidak memiliki keinginan dan motivasi untuk berperilaku secara adaptif. Klien halusinasi juga diperkirakan mengalami perubahan pada fungsi neurotransmitter, perubahan dopamin, serotonin, norepineprin dan asetilkolin yang menyebabkan adanya perubahan regulasi gerak dan koordinasi, emosi, kemampuan memecahkan masalah; perilaku cenderung negatif atau berperilaku maladaptif; terjadi kelemahan serta penurunan atensi dan mood.

Genetik juga dapa memicu terjadi halusinasi pada seorang individu.Faktor genetik dapat berperan dalam respon sosial maladaptif. Terjadinya penyakit jiwa pada individu juga dipengaruhi oleh keluarganya dibanding dengan individu yang tidak mempunyai penyakit terkait. Banyak riset menunjukkan peningkatan risiko mengalami skizofrenia pada individu dengan riwayat genetik terdapat anggota keluarga dengan skizofrenia. Pada kembar dizigot risiko terjadi skizofrenia $15 \%$, kembar monozigot 50\%, anak dengan salah satu orang tua menderita skizofrenia berisiko $13 \%$, dan jika kedua orang tua mendererita skizofrenia berisiko $45 \%$.

b. Psikologis 
Meliputi konsep diri, intelektualitas, kepribadian, moralitas, pengalaman masa lalu, koping dan keterampilan komunikasi secara verbal . Konsep diri dimulai dari gambaran diri secara keseluruhan yang diterima secara positif atau negatif oleh seseorang. Penerimaan gambaran diri yang negative menyebabkan perubahan persepsi seseorang dalam memandang aspek positif lain yang dimiliki.

Peran merupakan bagian terpenting dari konsep diri secara utuh. Peran yang terlalu banyak dapat menjadi beban bagi kehidupan seseorang, hal ini akan berpengaruh terhadap kerancuan dari peran dirinya dan dapat menimbulkan depresi yang berat. Ideal diri adalah harapan, cita-cita serta tujuan yang ingin diwujudkan atau dicapai dalam hidup secara realistis. Identitas diri terkait dengan kemampuan seseorang dalam mengenal siapa dirinya, dengan segala keunikannya. Harga diri merupakan kemampuan seseorang untuk menghargai diri sendiri serta member penghargaan terhadap kemampuan orang lain.

Klien yang mengalami halusinasi memandang dirinya secara negatif sering mengabaikan gambaran dirinya, tidak memperhatikan kebutuhannya dengan baik. Intelektualitas ditentukan oleh tingkat pendidikan seseorang, pengalaman dan interaksi dengan lingkungan ketika mengalami halusinasi. Kepribadian pada klien halusinasi biasanya ditemukan klien memiliki kepribadian yang tertutup. Klien tidak mudah menerima masukan dan informasi yang berkaitan dengan kehidupan klien. Klien juga jarang bergaul dan cenderung menutup diri. Klien memiliki ketidakmampuan untuk mengevaluasi atau menilai keadaan dirinya dan tidak mampu memutuskan melakukan peningkatan keadaan menjadi lebih baik.

Moralitas pandangan negatif terhadap diri sendiri ini menyebabkan klien mengalami penurunan motivasi untk melakukan aktifitas. Kesimpulannya, adanya penilaian diri yang negatif pada diri klien 
dengan halusinasi menyebabkan tidak ada tanggung jawab secara moral pada klien untuk melakukan aktifitas.

Menurut beberapa penjelasan di atas dapat diambil suatu kesimpulan bahwa jika mempunyai pengalaman masa lalu yang tidak menyenangkan, klien mempunyai konsep diri negatif, intelektualitas yang rendah, kepribadian dan moralitas yang tidak adekuat merupakan penyebab secara psikologis untuk terjadinya halusinasi. Klien halusinasi memerlukan perhatian yang cukup besar untuk dapat mengembalikan konsep diri yang seutuhnya yang menyebabkan klien suka menyendiri, melamun dan akhirnya muncul halusinasi.

\section{c. Sosial Budaya}

Meliputi status sosial, umur, pendidikan, agama, dan kondisi politik. Menurut Nyumirah, (2013) ada beberapa hal yang dikaitkan dengan masalah gangguan jiwa. Salah satunya yang terjadi pada klien halusinasi adalah masalah pekerjaan yang akan mempengaruhi status sosial. Klien dengan status sosial ekonomi yang rendah berpeluang lebih besar untuk mengalami gangguan jiwa dibandingkan dengan klien yang memiliki status sosial ekonomi tinggi.

Faktor sosial ekonomi tersebut meliputi kemiskinan, tidak memadainya sarana dan prasarana, tidak adekuatnya pemenuhan nutrisi, rendahnya pemenuhan kebutuhan perawatan untuk anggota keluarga, dan perasaan tidak berdaya. Kultur atau budaya, kepercayaan kebudayaan klien dan nilai pribadi mempengaruhi masalah klien dengan halusinasi. Berdasarkan beberapa pernyataan tersebut dapat disimpulkan bahwa status social ekonomi, pendidikan yang rendah, kurangnya pengetahuan, motivasi yang kurang dan kondisi fisik yang lemah dapat mempengaruhi klien dalam mempertahankan aktifitas klien yang mengalami halusinasi.

\section{Faktor Presipitasi}


Secara umum klien dengan gangguan halusinasi timbul gangguan setelah adanya hubungan yang bermusuhan, tekanan, isolasi, perasaan tidak berguna, putus asa dan tidak berdaya. Penilaian individu terhadap stressor dan masalah koping dapat mengindikasikan kemungkinan kekambuhan (Keliat, 2014). Faktor presipitasi sebagai suatu stimulus yang dipersepsikan oleh individu apakah dipersepsikan sebagai suatu kesempatan, tantangan, ancaman/tuntutan.

Stressor presipitasi bisa berupa stimulus internal maupun eksternal yang mengancam individu. Komponen stressor presipitasi terdiri atas sifat, asal, waktu dan jumlah stressor (Stuart, 2013). Sifat stresor, terjadinya halusinasi berdasarkan sifat terdiri dari :

a. Komponen biologis, misalnya penyakit infeksi, penyakit kronis atau kelainan struktur otak, ketidakteraturan dalam proses pengobatan.

b. Komponen psikologis, misalnya: intelegensi, ketrampilan verbal, moral, kepribadian dan kontrol diri, pengalaman yang tidak menyenangkan, kurangnya motivasi.

c. Komponen sosial budaya, misalnya: adanya aturan yang sering bertentangan antara individu dan kelompok masyarakat, tuntutan masyarakat yang tidak sesuai dengan kemampuan seseorang, ataupun adanya stigma dari masyarakat terhadap seseorang yang mengalami gangguan jiwa, sehingga klien melakukan perilaku yang terkadang menentang hal tersebut yang menurut masyarakat tidak sesuai dengan kebiasaan dan lingkungan setempat.

Asal stresor terdiri dari internal dan eksternal. Stresor internal atau yang berasal dari diri sendiri seperti persepsi individu yang tidak baik tentang dirinya, orang lain dan lingkungannya, merasa tidak mampu, ketidakberdayaan. Stresor eksternal atau berasal dari luar diri seperti kurangnya dukungan keluarga, dukungan masyarakat, dukungan kelompok/teman sebaya, dan lain-lain. Waktu dilihat sebagai dimensi kapan stresor mulai terjadi dan berapa lama terpapar stressor sehingga menyebabkan munculnya gejala. Lama dan jumlah stresor yaitu terkait 
dengan sejak kapan, sudah berapa lama, berapa kali kejadiannya (frekuensi) serta jumlah stresor (Stuart, 2013).

Saat pertama kali terkena masalah, maka penanganannya juga memerlukan suatu upaya yang lebih intensif dengan tujuan untuk pencegahan primer. Frekuensi dan jumlah stresor juga mempengaruhi individu, bila frekuensi dan jumlah stresor lebih sedikit juga akan memerlukan penanganan yang berbeda dibandingkan dengan yang mempunyai frekuensi dan jumlah stresor lebih banyak. Berbagai penyebab/stressor di atas, yang meliputi stressor predisposisi dan stressor presipitasi yang dialami oleh klien halusinasi akan memunculkan beberapa respon. Respon tersebut merupakan pikiran, sikap, tanggapan, perasaan dan perilaku yang ditunjukkan pada klien halusinasi terhadap kejadian yang dialami.

\subsubsection{Rentang Respon Neurobiologi}

Rentang respon neurobiologi (Stuart 2013) :

Adaptif Mal adaptif

\begin{tabular}{|l|l|l|}
\hline Pikiran logis & Kadang pikiran & Gangguan proses \\
Persepsi akurat & terganggu & pikir/delusi \\
Emosi konsisten & Ilusi & Halusinasi \\
dengan pengalaman & Emosi & Tidak mampu mengalami \\
Perilaku sesuai & berlebihan/kurang & emosi \\
Hubungan social & Perilaku yang tidak bisa & Perilaku tidak terorganisir \\
positif & Menarik diri & Isolasi social \\
& & \\
\hline
\end{tabular}

\section{Respon Adaptif}

Respon adaptif adalah respon yang dapat diterima norma-norma sosial budaya yang berlaku. Dengan kata lain individu tersebut dalam batas normal jika menghadapi suatu masalah akan dapat memecahkan masalah tersebut, respon adaptif:

a. Pikiran logis adalah pandangan yang mengarah pada kenyataan.

b. Persepsi akurat adalah pandangan yang tepat pada kenyataan. 
c. Emosi konsisten dengan pengalaman yaitu perasaan yang timbul dari pengalaman.

d. Perilaku sosial adalah sikap dan tingkah laku yang masih dalam batas kewajaran.

e. Hubungan sosial adalah proses suatu interaksi dengan orang lain dan lingkungan.

\section{Respon Psikososial}

Respon psikosial meliputi:

a. Proses pikir terganggu adalah proses pikir yang menimbulkan gangguan.

b. Ilusi adalah interpretasi atau penilaian yang salah tentang penerapan yang benar-benar terjadi (objek nyata) karena rangsangan panca indera.

c. Emosi berlebihan atau berkurang.

d. Perilaku tidak biasa adalah sikap dan tingkah laku yang melebihi batas kewajaran.

e. Menarik diri adalah percobaan untuk menghindar interaksi dengan orang lain.

\section{Respon Maladaptif}

Respon maladaptif adalah respon individu dalam menyelesaikan masalah yang menyimpang dari norma-norma sosial budaya dan lingkungan, adapun respon maladaptif meliputi:

a. Kelainan pikiran adalah keyakianan yang secara kokoh dipertahankan walaupun tidak diyakini oleh orang lain dan bertetangan dengan kenyataan sosial.

b. Halusinasi merupakan persepsi sensori yang salah atau persepsi eksternal yang tidak realita atau tidak ada.

c. Kerusakan proses emosi adalah perubahan sesuatu yang timbul dari hati.

d. Perilaku tidak terorganisir merupakan suatu yang tidak teratur. 
e. Isolasi sosial adalah kondisi kesendirian yang dialami oleh individu dan diterima sebagai ketentuan oleh orang lain dan sebagai suatu kecelakaan yang negatif mengancam.

\subsubsection{Fase Halusinasi}

Halusinasi terbagi atas beberapa fase menurut Kanine (2012) yaitu:

a. Fase Pertama / comforting / menyenangkan

Pada fase ini klien mengalami kecemasan, stress, perasaan gelisah, kesepian. Klien mungkin melamun atau memfokukan pikiran pada hal yang menyenangkan untuk menghilangkan kecemasan dan stress. Cara ini menolong untuk sementara. Klien masih mampu mengotrol kesadarnnya dan mengenal pikirannya, namun intensitas persepsi meningkat.

Perilaku klien : tersenyum atau tertawa yang tidak sesuai, menggerakkan bibir tanpa bersuara, pergerakan mata cepat, respon verbal yang lambat jika sedang asyik dengan halusinasinya dan suka menyendiri.

b. Fase Kedua / comdemming

Kecemasan meningkat dan berhubungan dengan pengalaman internal dan eksternal, klien berada pada tingkat "listening" pada halusinasi. Pemikiran internal menjadi menonjol, gambaran suara dan sensasi halusinasi dapat berupa bisikan yang tidak jelas klien takut apabila orang lain mendengar dan klien merasa tak mampu mengontrolnya. Klien membuat jarak antara dirinya dan halusinasi dengan memproyeksikan seolah-olah halusinasi datang dari orang lain.

Perilaku klien : meningkatnya tanda-tanda sistem saraf otonom seperti peningkatan denyut jantung dan tekanan darah. Klien asyik dengan halusinasinya dan tidak bisa membedakan dengan realitas.

c. Fase Ketiga / controlling 
Halusinasi lebih menonjol, menguasai dan mengontrol klien menjadi terbiasa dan tak berdaya pada halusinasinya. Termasuk dalam gangguan psikotik.

Karakteristik : bisikan, suara, isi halusinasi semakin menonjol, menguasai dan mengontrol klien. Klien menjadi terbiasa dan tidak berdaya terhadap halusinasinya.

Perilaku klien : kemauan dikendalikan halusinasi, rentang perhatian hanya beberapa menit atau detik. Tanda-tanda fisik berupa klien berkeringat, tremor dan tidak mampu mematuhi perintah.

d. Fase Keempat / conquering/ panik

Klien merasa terpaku dan tak berdaya melepaskan diri dari kontrol halusinasinya. Halusinasi yang sebelumnya menyenangkan berubah menjadi mengancam, memerintah dan memarahi klien tidak dapat berhubungan dengan orang lain karena terlalu sibuk dengan halusinasinya klien berada dalam dunia yang menakutkan dalam waktu singkat, beberapa jam atau selamanya. Proses ini menjadi kronik jika tidak dilakukan intervensi.

Perilaku klien : perilaku teror akibat panik, potensi bunuh diri, perilaku kekerasan, agitasi, menarik diri atau katatonik, tidak mampu merespon terhadap perintah kompleks dan tidak mampu berespon lebih dari satu orang.

\subsubsection{Komplikasi}

Halusinasi dapat menjadi suatu alasan mengapa klien melakukan tindakan perilaku kekerasan karena suara-suara yang memberinya perintah sehingga rentan melakukan perilaku yang tidak adaptif. Perilaku kekerasan yang timbul pada klien skizofrenia diawali dengan adanya perasaan tidak berharga, takut dan ditolak oleh lingkungan sehingga individu akan menyingkir dari hubungan interpersonal dengan orang lain (Keliat, 2014). 
Komplikasi yang dapat terjadi pada klien dengan masalah utama gangguan sensori persepsi: halusinasi, antara lain: resiko prilaku kekerasan, harga diri rendah dan isolasi sosial.

\subsubsection{Penatalaksanaan Medis}

Halusinasi merupakan salah satu gejala yang paling sering terjadi pada gangguan Skizofrenia. Dimana Skizofrenia merupakan jenis psikosis, adapun tindakan penatalaksanaan dilakukan dengan berbagai terapi yaitu dengan:

\section{Psikofarmakologis}

Obat sangat penting dalam pengobatan skizofrenia, karena obat dapat membantu pasien skizofrenia untuk meminimalkan gejala perilaku kekerasan, halusinasi, dan harga diri rendah. Sehingga pasien skizofrenia harus patuh minum obat secara teratur dan mau mengikuti perawatan (Pardede, Keliat, Wardani, 2013):

a. Haloperidol (HLD)

Obat yang dianggap sangat efektif dalam pengelolaan hiperaktivitas, gelisah, agresif, waham, dan halusinasi.

b. Chlorpromazine (CPZ)

Obat yang digunakan untuk gangguan psikosis yang terkait skizofrenia dan gangguan perilaku yang tidak terkontrol

c. Trihexilpenidyl (THP)

Obat yang digunakan untuk mengobati semua jenis parkinson dan pengendalian gejala ekstrapiramidal akibat terapi obat.

1) Dosis

- $\quad$ Haloperidol 3x5 mg (tiap 8 jam) intra muscular. 
- Clorpromazin 25-50 mg diberikan intra muscular setiap 6-8 jam sampai keadaan akut teratasi.

2) Dalam keadaan agitasi dan hiperaktif diberikan tablet:

- Haloperidol 2x1,5 - 2,5 mg per hari.

- $\quad$ Klorpromazin 2x100 mg per hari

- $\quad$ Triheksifenidil $2 \times 2 \mathrm{mg}$ per hari

3) Dalam keadaan fase kronis diberikan tablet:

- Haloperidol 2x0,5 - $1 \mathrm{mg}$ perhari

- $\quad$ Klorpromazin 1x50 mg sehari (malam)

- $\quad$ Triheksifenidil 1-2x2 mg sehari

- Psikosomatik

Terapi kejang listrik (Electro Compulsive Therapy), yaitu suatu terapi fisik atau suatu pengobatan untuk menimbulkan kejang grand mal secara artifisial dengan melewatkan aliran listrik melalui elektroda yang dipasang pada satu atau dua temples pada pelipis. Jumlah tindakan yang dilakukan merupakan rangkaian yang bervariasi pada setiap pasien tergantung pada masalah pasien dan respon terapeutik sesuai hasil pengkajian selama tindakan. Pada pasien Skizofrenia biasanya diberikan 30 kali. ECT biasanya diberikan 3 kali seminggu walaupun biasanya diberikan jarang atau lebih sering. Indikasi penggunaan obat: penyakit depresi berat yang tidak berespon terhadap obat, gangguan bipolar di mana pasien sudah tidak berespon lagi terhadap obat dan pasien dengan bunuh diri akut yang sudah lama tidak mendapatkan pertolongan.

1. Psikoterapi

Membutuhkan waktu yang relatif lama, juga merupakan bagian penting dalam proses terapeutik. Upaya dalam psikoterapi ini meliputi: memberikan rasa aman dan tenang, menciptakan lingkungan terapeutik, memotivasi klien untuk dapat mengungkapkan perasaan secara verbal, bersikap ramah, sopan, dan jujur terhadap klien. 


\subsubsection{Prinsip Keperawatan}

Menetapkan hubungan terapeutik, kontak sering dan singkat secara bertahap, peduli, empati, jujur, menepati janji dan memenuhi kebutuhan dasar klien. Pada umumnya melindungi dari perilaku yang membahayakan, tidak membenarkan ataupun menyalahkan halusinasi klien, melibatkan pasien dan keluarga dalam perencanaan asuhan keperawatan dan mempertahankan perilaku keselarasan verbal dan nonverbal.

\subsubsection{Pelaksanaan Keperawatan}

Implementasi disesuaikan dengan rencana tindakan keperawatan. Pada situasi nyata sering pelaksanaan jauh berbeda dengan rencana, hal ini terjadi karena perawat belum terbiasa menggunakan rencana tertulis dalam melaksanakan tindakan keperawatan. Sebelum melaksanakan tindakan keperawatan yang sudah direncanakan, perawat perlu memvalidasi dengan singkat apakah rencana tindakan masih sesuai dan dibutuhkan klien sesuai dengan kondisinya (here and now). Perawat juga menilai diri sendiri, apakah kemampuan interpersonal, intelektual, tekhnikal sesuai dengan tindakan yang akan dilaksanakan, dinilai kembali apakah aman bagi klien. Setelah semuanya tidak ada hambatan maka tindakan keperawatan boleh dilaksanakan.

Adapun pelaksanaan tindakan keperawatan jiwa dilakukan berdasarkan Strategi Pelaksanaan (SP) yang sesuai dengan masing-masing masalah utama. Pada masalah gangguan sensori persepsi: halusinasi pendengaran, terdapat 2 jenis SP, yaitu SP Klien dan SP Keluarga.

SP klien terbagi menjadi SP 1 (membina hubungan saling percaya, mengidentifikasi halusinasi "jenis, isi, waktu, frekuensi, situasi, perasaan dan respon halusinasi", mengajarkan cara menghardik, memasukan cara menghardik ke dalam jadwal; SP 2 (mengevaluasi SP 1, mengajarkan cara minum obat secara teratur, memasukan ke dalam 
jadwal);SP 3 (mengevaluasi SP 1 dan SP 2, menganjurkan klien untuk mencari teman bicara); SP 4 (mengevaluasi SP 1, SP 2, dan SP 3, melakukan kegiatan terjadwal).

SP keluarga terbagi menjadi SP 1 (membina hubungan saling percaya, mendiskusikan masalah yang dihadapi keluarga dalam merawat pasien, menjelaskan pengertian, tanda dan gejala helusinasi, jenis halusinasi yang dialami klien beserta proses terjadinya, menjelaskan cara merawat pasien halusinasi); SP 2 (melatih keluarga mempraktekan cara merawat pasien dengan halusinasi, melatih keluarga melakukan cara merawat langsung kepada pasien halusinasi); SP 3 (membantu keluarga membuat jadwal aktivitas di rumah termasuk minum obat (discharge planing), menjelaskan follow up pasien setelah pulang).

Pada saat akan dilaksanakan tindakan keperawatan maka kontrak dengan klien dilaksanakan dengan menjelaskan apa yang akan dikerjakan dan peran serta klien yang diharapkan, dokumentasikan semua tindakan yang telah dilaksanakan serta respon klien.

\subsubsection{Evaluasi Keperawatan}

Evaluasi adalah proses yang berkelanjutan untuk menilai efek dari tindakan keperawatan pada klien (Dalami, 2009). Evaluasi dilakukan terus menerus pada respon klien terhadap tindakan yang telah dilaksanakan, evaluasi dapat dibagi dua jenis yaitu: evaluasi proses atau formatif dilakukan selesai melaksanakan tindakan. Evaluasi hasil atau sumatif dilakukan dengan membandingkan respon klien pada tujuan umum dan tujuan khusus yang telah ditentukan.

Evaluasi keperawatan yang diharapkan pada pasien dengan gangguan sensori persepsi: halusinasi pendengaran adalah: tidak terjadi perilaku kekerasan, klien dapat membina hubungan saling percaya, klien dapat mengenal halusinasinya, klien dapat mengontrol halusinasinya, klien 
mendapatkan dukungan dari keluarga dalam mengontrol halusinasinya, klien dapat menggunakan obat dengan baik dan benar.

BAB III

TINJAUAN KASUS

\subsection{Identitas Klien}

Inisial

: Tn.P 


$\begin{array}{ll}\text { Tanggal Pengkajian } & : \text { 8Februari } 2019 \\ \text { Umur } & : 32 \text { Tahun } \\ \text { Agama } & : \text { Islam } \\ \text { Informan } & : \text { Klien dan Status Klien }\end{array}$

\subsection{Alasan Masuk}

Klien Awalnya marah-marah dan melempar barang-barang karena kesal, suka menyendiri, melamun, sering bicara sendiri, mondar mandir, mendengar suara-suara tanpa wujud, tertawa sendiri.

\subsection{Faktor Predisposisi}

Klien sebelumnya belum pernah mengalami gangguan jiwa. Gangguan jiwa yang dialami klien bermula disaat dia ditinggal menikah oleh tunangannya. Karena tunangannya lebih memilih laki-laki yang mapan daripada Tn.P. Hal tersebut mengakibatkan Tn.P mengalami gejala-gejala seperti diatas kemudian. Klien awalnya marah-marah dan melempar barang-barang karena kesal, suka menyendiri, melamun, sering bicara sendiri, mondar mandir, mendengar suara-suara tanpa wujud, tertawa sendiri akhirnya keluarga membawa klien ke psikiater, dukun, ustad dan pengobatan yang lainnya. Gejala yang dialami perlahan berkurang namun akhir-akhir ini masalahnya kembali lagi muncul karena tidak dikontrol untuk berobat dan juga dia jarang minum obat.

Masalah Keperawatan:Resiko Perilaku kekerasan

Regiment individu Terapeutikinefektif

\subsection{Fisik}

Klien tidak memiliki keluhan fisik, saat dilakukan pemeriksaan tanda-tanda vital, didapatkan hasil TD : 130/80 mmHg ; $\mathrm{N}: 78 \mathrm{x} / \mathrm{i} ; \mathrm{S}: 37^{\circ} \mathrm{C} ; \mathrm{P}: 20 \mathrm{x} / \mathrm{i}$. Klien memiliki tinggi badan $170 \mathrm{~cm}$ dan berat badan $58 \mathrm{Kg}$. 


\subsection{Psikososial}

\subsubsection{Genogram}

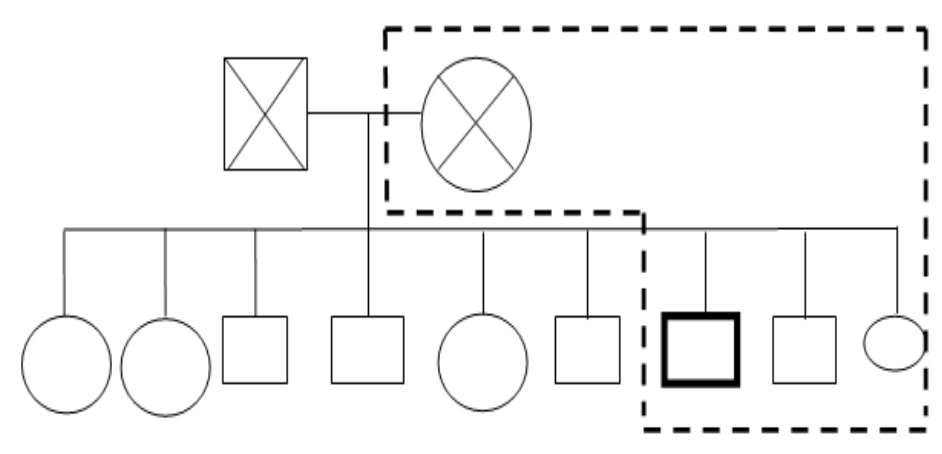

Penjelasan :

Klien merupakan anak ke Tujuh dari 9 bersaudara,klien memiliki tiga abang dan 3 kakak perempuan. Klien belum menikah.

Keterangan :

$\square \quad$ : Laki-laki

$\bigcirc$ : Perempuan

$\square$ : Klien

---- : Tinggal dalam satu rumah

Х: meninggal

\subsubsection{Konsep diri}

a. Gambaran diri: Klien menyukai seluruh tubuhnya dan tidak ada yang cacat 
b. Identitas : Klien anak ke 7 dari 9 bersaudara, klien hanya lulusan SD yang saat ini bekerja sebagai kuli bangunan

c. Peran : Klien berperan sebagai anak

d. Ideal diri $\quad$ : Klien merasa malu karena klien tidak bisa mengendalikan dirinya sendri.

e. Harga diri $\quad$ : Klien mengatakan merasa malu karena tidak mapan dan akhirnya ditinggalkan oleh tunangannya

Masalah keperawatan:Gangguan konsep diri : harga diri rendah

\subsubsection{Hubungan social}

Klien mengganggap bahwa keluarganya adalah orang yang sangat berarti dalam hidupnya, terutama orangtuanya. Klien tidak mengikuti kegiatan di kelompok/masyarakat. Klien mengatakan mempunyai hambatan dalam berhubungan dengan orang lain karena klien sulit bergaul dan selalu ingin menyendiri.

Masalah keperawatan:Isolasi Sosial : Menarik diri

\subsubsection{Spiritual}

a. Nilai dan Keyakinan: Klien beragama Islam dan yakin dengan agamanya.

b. Kegiatan Ibadah : Klien tidak ikut melakukan ibadah selama dirawat.

Masalah keperawatan: Tidak Ada Masalah Keperawatan

\subsubsection{Status Mental}

1. Penampilan

Penjelasan :Klien tampak kurang rapi dalam berpakaian 
Masalah keperawatan :Tidak Ada Masalah Keperawatan

2. Pembicaraan

Penjelasan :Klien masih mampu menjawab pertanyaan perawat dengan lambat namun dapat dipahami

Masalah keperawatan : Tidak Ada Masalah Keperawatan

3. Aktivitas Motorik

Penjelasan : tidak ada masalah

4. Suasana perasaan

Penjelasan:Klien sedih karena tinggal di rumah sakit

Masalah keperawatan :Harga Diri Rendah

5. Afek

Penjelasan :afek wajah sesuai dengan topic pembicaraan

Masalah keperawatan :tidak ada masalah

6. Interaksi selama wawancara

Penjelasan :Klien kooperatif saat wawancara

Masalah keperawatan : Tidak ada masalah

7. Persepsi

Penjelasan :Klien mengatakan bahwa ia mendengar ada suara-suara

Masalah keperawatan : Gangguan persepsi sensori : halusinasi

8. Proses Pikir

Penjelasan : Klien mampu menjawab apa yang ditanya dengan baik.

Masalah keperawatan : Tidak ada masalah keperawatan

9. Isi piker

Penjelasan :Klien dapat mengontrol isi pikirnya,klien tidak mengalami gangguan isi pikir dan tidak ada waham. Klien tidak mengalami fobia, obsesi ataupun depersonalisasi.

Masalah Keperawatan : Tidak ada masalah keperawatan

10. Tingkat kesadaran

Penjelasan :Klien tidak mengalami gangguan orientasi, klien mengenali waktu, orang dan tempat.

Masalah keperawatan :Tidak Ada Masalah Keperawatan

11. Memori 
Penjelasan :Klien mampu menceritakan kejadian di masa lalu dan yang baru terjadi.

Masalah Keperawatan :Tidak Ada Masalah Keperawatan

12. Tingkat konsentrasi berhitung

Penjelasan:Klien mampu berkonsentrasi dalam perhitungan

sederhana tanpa bantuan orang lain.

Masalah keperawatan : Tidak Ada Masalah Keperawatan

13. Kemampuan penilaian

Penjelasan : Klien dapat membedakan hal yang baik dan yang buruk (mampu melakukan penilaian)

Masalah keperawatan : Tidak Ada Masalah Keperawatan

14. Daya tilik diri

Penjelasan: Klien tidak mengingkari penyakit yang diderita, klien mengetahui bahwa dia sedang sakit dan dirawat di rumah sakit jiwa.

Masalah keperawatan :Tidak Ada Masalah Keperawatan

\subsection{Mekanisme Koping}

Klien mengalami mekanisme koping adaptif yaitu klien dapat berbicara baik dengan orang lain.

\subsection{Masalah Psikososial dan Lingkungan}

Klien mengatakan sulit berteman dengan orang lain karena klien selalu ingin menyendiri.

\subsection{Pengetahuan Kurang Tentang Gangguan Jiwa}

Klien tidak mengetahui tentang gangguan jiwa yang di alaminya dan obat yang dikonsumsinya.

\subsection{Aspek Medik}

Diagnosa medis : Skizofrenia Paranoid

Terapi medis yang diberikan:

a. Resperidon tablet $2 \mathrm{mg} 2 \times 1$ 
b. Chlozapine tablet $25 \mathrm{mg} \mathrm{1x1}$ 


\subsection{Pohon Masalah}

Resiko Prilaku Kekerasan

Gangguan Persepsi Sensorik : Halusinasi Pendengaran

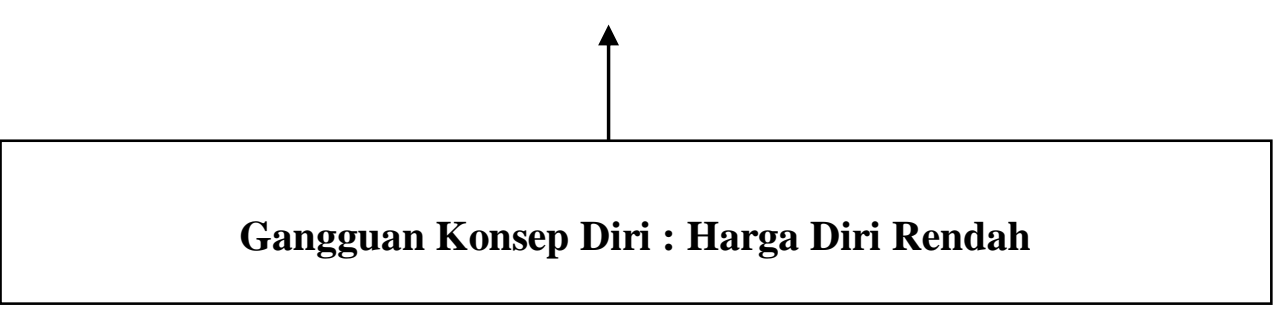

\subsection{Diagnosa Keperawatan}

Gangguan Persepsi Sensorik : Halusinasi Pendengaran

\subsection{Intervensi Keperawatan}

\begin{tabular}{|c|c|c|c|}
\hline $\begin{array}{c}\text { Diagnosa } \\
\text { Keperawatan }\end{array}$ & Tujuan & Kriteria Hasil & Intervensi \\
\hline $\begin{array}{l}\text { Gangguan persepsi ; } \\
\text { Halusinasi } \\
\text { Pendengaran }\end{array}$ & $\begin{array}{l}\text { Klien dapat } \\
\text { mebina hubungan } \\
\text { saling percaya }\end{array}$ & $\begin{array}{l}\text { klien mampu } \\
\text { mempercayai } \\
\text { perawat, dank lien } \\
\text { bisa menerima } \\
\text { semua apa yang telah } \\
\text { diajarin dan } \\
\text { diberikan masukkan } \\
\text { kepada klien }\end{array}$ & $\begin{array}{l}\text { 1. Membina hubungan } \\
\text { saling percaya dengan } \\
\text { cara (menjelaskan } \\
\text { maksut dan tujuan } \\
\text { interaksi, jelaskan } \\
\text { tentang kontrak yang } \\
\text { akan dibuat, beri rasa } \\
\text { aman dan sikap } \\
\text { empati). 2. Diskusikan } \\
\text { bersama klien tentang } \\
\text { halusinasi yang }\end{array}$ \\
\hline
\end{tabular}




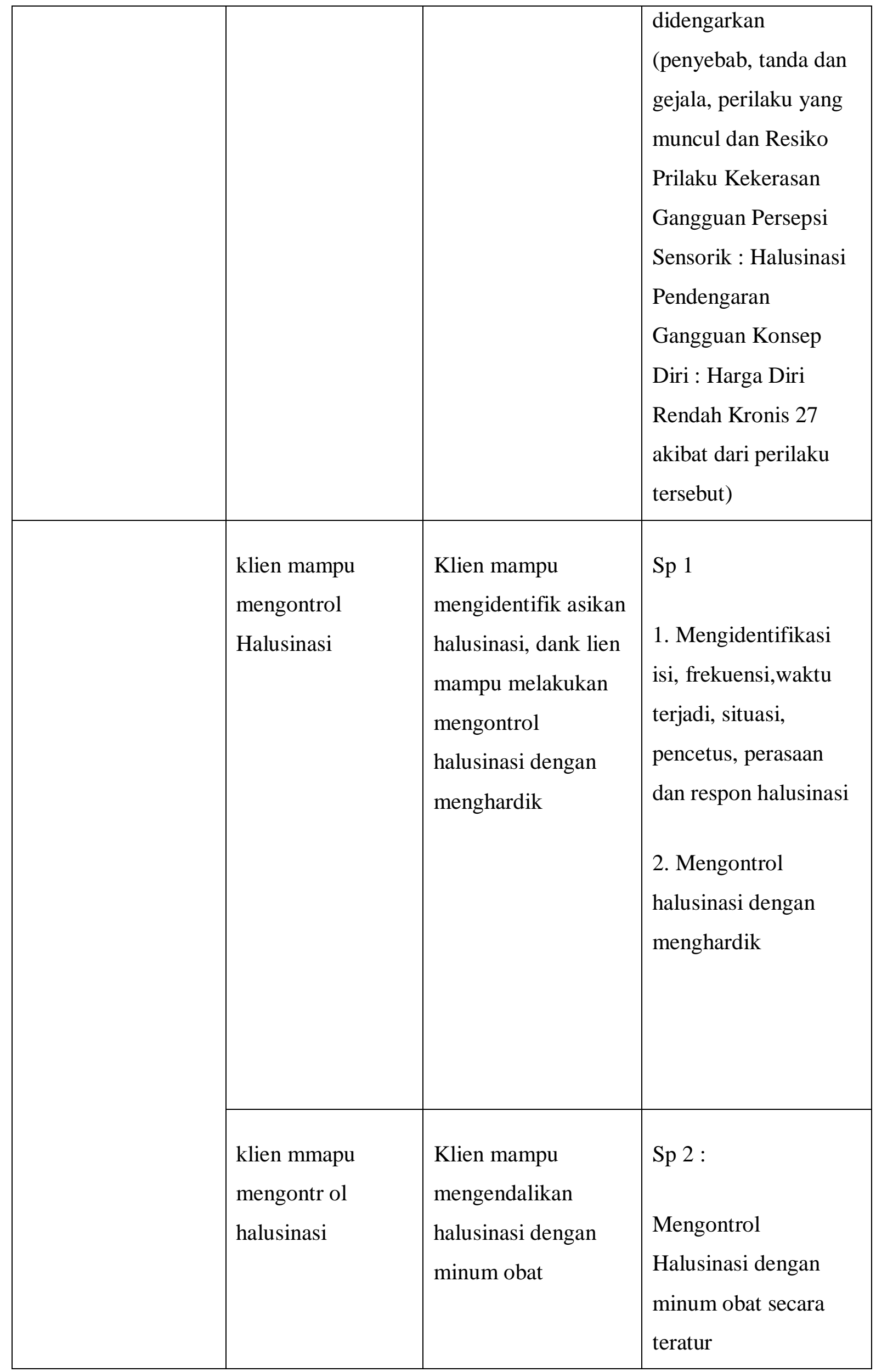




\begin{tabular}{|c|c|c|c|}
\hline & $\begin{array}{l}\text { klien mampu } \\
\text { mengontrol } \\
\text { halusinasi dank } \\
\text { lien mampu } \\
\text { bersosialisa si } \\
\text { dengan orang lain } \\
\text { dan keluarga }\end{array}$ & $\begin{array}{l}\text { klien mampu dan } \\
\text { faham mengontrol } \\
\text { halusisasi dengan } \\
\text { berbicara dengan } \\
\text { kluarga dan orang } \\
\text { lain }\end{array}$ & $\begin{array}{l}\text { SP } 3 \text { : } \\
\text { Mengontrol halusinasi } \\
\text { dengan bercakap- } \\
\text { cakap } 28 \text { halusinasi } \\
\text { dank lien mampu } \\
\text { bersosialisa si dengan } \\
\text { orang lain dan } \\
\text { keluarga halusisasi } \\
\text { dengan berbicara } \\
\text { dengan kluarga dna } \\
\text { orang lain dengan } \\
\text { orang lain. }\end{array}$ \\
\hline & $\begin{array}{l}\text { klien mampu } \\
\text { mengontrol } \\
\text { halusinasi }\end{array}$ & $\begin{array}{l}\text { klien mampu } \\
\text { melaukan kegiatan } \\
\text { dan mengontrol } \\
\text { halusinasi }\end{array}$ & $\begin{array}{l}\text { SP } 4 \text { : } \\
\text { Mengontrol halusinasi } \\
\text { dengan melakukan } \\
\text { legiatan terjadwal }\end{array}$ \\
\hline Harga diri rendah & & & $\begin{array}{l}\text { Sp 1: } \\
\text { Mengidentifikasi } \\
\text { kemampuan dan aspek } \\
\text { positif yang dimiliki } \\
\text { pasien Sp } 2 \text { : a. } \\
\text { menilai kemampuan } \\
\text { yang dapat digunakan } \\
\text { b. Mendapatkan atau } \\
\text { memiliki kegiatan } \\
\text { sesuai kemampuan Sp } \\
\text { 3 : Melatih kegiatan } \\
\text { sesuai kemampuan } \\
\text { yang dipilih Sp } 4 \text { : } \\
\text { Melatih kegiatan } \\
\text { sesuai kemampuan }\end{array}$ \\
\hline
\end{tabular}




\begin{tabular}{|l|l|l|}
\hline Resiko Perilaku & & yang dipilih. \\
\hline kekrasan & & $\begin{array}{l}\text { Sp 1 : mengontrol } \\
\text { perilaku 29 Kekerasan } \\
\text { kekerasan dengan cara } \\
\text { a. Latihan fisik : Tarik } \\
\text { Nafas dalam b. } \\
\text { Latihan fisik : pukul } \\
\text { bantal Sp 2: } \\
\text { mengontrol perilaku } \\
\end{array}$ \\
& kekerasan dengan cara \\
& minum obat secara \\
& teratur Sp 3 : \\
& komunikasi verbal : \\
& asektif (berbicara \\
& dengan bak). Sp 4: \\
& Spritual \\
\hline
\end{tabular}

\subsection{Implementasi dan Evaluasi}

\section{Hari/tgl}




\begin{tabular}{|c|c|c|}
\hline $\begin{array}{l}\text { selasa /16- } \\
02-2021\end{array}$ & $\begin{array}{l}\text { 1. Data : } \\
\text { Tanda dan gejala : pasien } \\
\text { tampak ketakutan dan } \\
\text { merasa cemas dengan } \\
\text { suara yang } \\
\text { didengarnya. } \\
\text { Kemampuan : meminum } \\
\text { air putih ketika } \\
\text { merasa cemas ketika } \\
\text { suara bisikan itu } \\
\text { datang } \\
\text { 2. Diagnosa } \\
\text { Keperawatan } \\
\text { gangguan persepsi } \\
\text { sensori : Halusinasi } \\
\text { pendengaran } \\
\text { Tindakan } \\
\text { keperawatan: } \\
\text { Sp 1: } \\
\text { - Mengidentifikasi isi, } \\
\text { frekuensi waktu } \\
\text { terjadi, situasi, } \\
\text { pencetus, perasaan } \\
\text { dan respon halusinasi } \\
\text { Suara yang dating } \\
\text { dibisan pasien } \\
\text { memat klien takut } \\
\text { - dan suara }\end{array}$ & 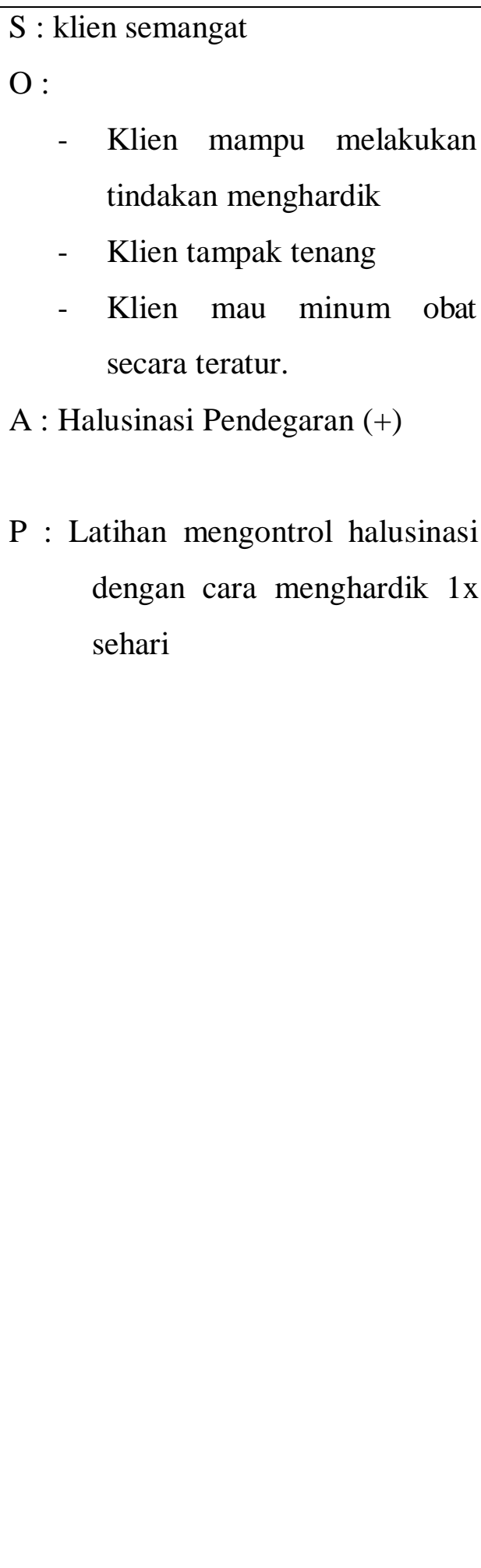 \\
\hline
\end{tabular}




\subsection{Konsep Asuhan Keperawatan}

\section{Pengkajian}

Pengkajian merupakan pengumpulan data subjektif dan objektif secara, sistematis dengan tujuan membuat penentuantindakan keperawatan bagi individu,kekuarga dan komunitas (Damayanti 2014). Pada tahap ini ada beberapa yang perlu dieksplorasi baik pada klien yang berkenaan dengan kasus halusinasi yang meliputi :

1. Identitas klien

Meliputi nama klien, umur, jenis kelamin, status perkawinan, Agama, tanggal MRS, informan, tanggal pengkajian, nomor rumah klien, dan alamat klien.

a. Keluhan utama

Keluhan utama Biasanya berupa bicara sendiri, tertawa sendiri, senyum sendiri, menggerakkan bibir tanpa suara, menarik diri dari orang lain, tidak dapat membedakan yang nyata dan tidak nyata, ekspresi muka tegang mudah tersinggung, jengkel dan marah ketakutan biasa terdapat disorientasi waktu tempat dan orang, tidak dapat mengurus diri dan tidak melakukan kegiatan sehari-hari.

b. Faktor predisposisi

Faktor predisposisi adalah faktor resiko yang mempengaruhi jenis dan jumlah sumber yang dapat dibangkitkan oleh individu untuk mengatasi stres. Diperoleh baik dari klien maupun keluarganya, mengenai faktor perkembangan sosial kultural, biokimia psikologis dan genetik yaitu faktor resiko yang mempengaruhi jenis dan jumlah sumber yang dapat dibangkitkan oleh individu untuk mengatasi stres.

c. Faktor perkembangan ; biasanya tugas perkembangan mengalami hambatan dan hubungan interpersonal terganggu maka individu akan mengalami stres dan 
kecemasan.

d. Faktor sosiokultural ; berbagai faktor di masyarakat dapat menyebabkan seseorang merasa disingkirkan oleh kesepian terhadap lingkungan tempat klien dibesarkan.

e. Faktor biokimia ; adanya stres yang berlebihan dialami seseorang maka di dalam tubuh akan dihasilkan suatu zat yang dapat bersifat halusinogenik neuro kimia.

f. Faktor psikologis; hubungan interpersonal yang tidak harmonis, adanya peran ganda yang bertentangan dan tidak diterima oleh anak akan mengakibatkan stres dan kecemasan yang tinggi dan berakhir dengan gangguan orientasi realitas seperti halusinasi.

g. Faktor genetik; Apa yang berpengaruh dalam skizoprenia. Belum diketahui, tetapi Hasil studi menunjukkan bahwa faktor keluarga menunjukkan hubungan yang sangat berpengaruh pada penyakit ini.

\section{Faktor presipitasi}

Adanya rangsangan lingkungan yang sering yaitu seperti partisipasi klien dalam kelompok, terlalu lama Diajak komunikasi objek yang ada di lingkungan juga suasana sepi / isolasi adalah sering sebagai pencetus terjadinya halusinasi karena hal tersebut dapat meningkatkan stres dan kecemasan yang merangsang tubuh mengeluarkan zat halusinogenik.

3. Aspek fisik

Hasil pengukuran tanda vital (TD, nadi, suhu, pernapasan, TB, BB) dan keluhan fisik yang dialami oleh klien. Terjadi peningkatan denyut jantung pernapasan dan tekanan darah.

4. Aspek psikososial

Genogram yang menggambarkan tiga generasi.

5. Konsep diri

a. Citra tubuh

Menolak melihat dan menyentuh bagian tubuh yang 
berubah/ tidak menerima perubahan tubuh yang terjadi / yang akan terjadi. Menolak penjelasan perubahan tubuh, persepsi negatif tentang tubuh. Preokupasi dengan bagian tubuh yang hilang, mengungkapkan keputusasaan, mengungkapkan ketakutan.

b. Identitas diri

Ketidakpastian memandang diri, sukar menetapkan keinginan dan tidak mampu mengambil keputusan.

c. Peran

Berubah / berhenti fungsi peran yang disebabkan penyakit, proses menua putus sekolah dan PHK.

d. Identitas diri

Mengungkapkan keputusasaan karena penyakitnya dan mengungkapkan keinginan yang terlalu tinggi

e. Harga diri

Perasaan malu terhadap diri sendiri, rasa bersalah terhadap diri sendiri, gangguan hubungan sosial, merendahkan martabat, mencederai diri dan kurang percaya diri.

6. Status mental

Pada pengkajian status mental pasien halusinasi ditemukan data berupa bicara sendiri, senyum sendiri, tertawa sendiri, menggerakkan bibir tanpa suara, pergerakan mata yang cepat, respon verbal yang lambat, menarik diri dari orang lain berusaha untuk menghindari orang lain, tidak dapat membedakan yang nyata dan tidak nyata, terjadi peningkatan denyut jantung pernapasan dan tekanan darah, perhatian dengan lingkungan yang kurang / hanya beberapa detik com berkonsentrasi dengan pengalaman sensori, sulit berhubungan dengan orang lain, ekspresi muka tegang, mudah tersinggung, jengkel dan marah tidak mampu mengikuti perintah dari 
perawat, tampak tremor dan berkeringat, perilaku panik, agitasi dan kataton curiga dan bermusuhan, bertindak merusak diri orang lain dan lingkungan, ketakutan, tidak dapat mengurus diri, biasa terdapat disorientasi waktu tempat dan orang.

7. Mekanisme koping

Apabila mendapat masalah, pasien takut / tidak mau menceritakan kepada orang lain (koping menarik diri). Mekanisme koping yang digunakan pasien sebagai usaha mengatasi kecemasan yang merupakan suatu kesepian nyata yang mengancam dirinya. Mekanisme koping yang sering digunakan pada halusinasi adalah

a. Regresi : menjadi malas beraktivitas sehari-hari.

b. Proyeksi : menjelaskan perubahan suatu persepsi dengan berusaha untuk mengalihkan tanggung jawab kepada orang lain.

c. Menarik diri : sulit mempercayai orang lain dan asyik dengan stimulus internal.

8. Aspek medik

Terapi yang diterima klien bisa berupa terapi farmakologi psikomotor terapi okupasional, TAK dan rehabilitas.

\section{Diagnosa Keperawatan}

Ada beberapa diagnosa keperawatan yang sering ditemukan pada klien dengan halusinasi (Damayanti, 2014) yaitu:
a. Gangguan sensori persepsi halusinasi
b. Harga diri rendah
c. Isolasi Sosial
d. Resiko tinggi perilaku kekerasan 


\section{Intervensi Keperawatan}

Tindakan keperawatan merupakan alat yang dijadikan sebagai panduan oleh seorang perawat jiwa ketika berinteraksi dengan kli en dengan gangguan halusinasi. Strategi pelaksanaan adalah penerapan standar asuhan keperawatan yang diterapkan pada pasien yang bertujuan untuk mengurangi masalah keperawatan jiwa yang ditangani. Strategi pelaksanaan pada pasien halusinasi mencakup kegiatan mengenal halusinasi,mengajarkan pasien menghardik, mengajarkan pasien bercakap-cakap dengan orang lain saat halusinasi muncul, serta melakukan aktifitas terjadwal untuk mencegah halusinasi (Susilawati,2019).

\section{Implamentasi Keperawatan}

Menurut Febryanty (2015). Pelaksanaan keperawatan merupakan proses keperawatan yang mengikuti rumusan dari rencana keperawatan. Pelaksanaan keperawatan mencakup melakukan, memberikan askep untuk mencapai tujuan yang berpusat pada klien. Pada diagnosa gangguan sensori persepsi halusinasi disesuaikan dengan rencana tindakan keperawatan, yang terdiri dari strategi pelaksanaan untuk klien dan strategi pelaksanaan untuk keluarga.

1. Strategi pelaksanaan untuk pasien Strategi pelaksanaan I :

a. Mengidentifikasi jenis halusinasi pasien.

b. Mengidentifikasi isi halusinasi pasien.

c. Mengidentifikasi waktu halusinasi pasien.

d. Mengidentifikasi frekuensi halusinasi pasien.

e. Mengidentifikasi situasi yang menimbulkan halusinasi.

f. Mengidentifikasi respons pasien terhadap halusinasi.

g. Mengajarkan pasien menghardik halusinasi.

h. Menganjurkan pasien memasukkan cara menghardik halusinasi dalam jadwal kegiatan harian. 
2. Strategi pelaksanaan untuk keluarga Strategi pelaksanaan I :

a. Mendiskusikan masalah yang dirasakan keluarga dalam merawat pasien.

b. Menjelaskan pengertian, tanda dan gejala halusinasi, dan jenis halusinasi yang dialami pasien beserta proses terjadinya.

c. Menjelaskan cara-cara merawat pasien halusinasi. Strategi pelaksanaan II :

a. Melatih keluarga mempraktekkan cara merawat pasien dengan halusinasi.

b. Melatih keluarga melakukan cara merawat langsung kepada pasien halusinasi.

\section{Evaluasi Keperawatan}

Menurut Dalami, (2014). Evaluasi dapat dilakukan dengan menggunakan pendekatan SOAP sebagai pola pikir, dimana masing- masing huruf tersebut akan diuraikan sebagai berikut :

S : Respon subjektif klien terhadap tindakan keperawatan yang telah dilaksanakan.

O : Respon objektif klien terhadap tindakan keperawatan yang telah dilaksanakan.

A : Analisa ulang terhadap data subjektif untuk menyimpulkan apakah masalah masih tetap atau muncul masalah baru atau ada yang kontradiksi dengan masalah yang ada.

P : Perencanaan atau tindak lanjut berdasarkan hasil analisa pada respon klien. 


\section{BAB 4 \\ PEMBAHASAN}

Setelah penulis melaksanakan asuhan keperawat kepada Tn.P dengan gangguan sensori persepsi: halusinasi pendengaran di ruang Jalan Setia Luhur gang Horas maka penulis pada $\mathrm{BAB}$ ini akan membahasan kesenjangan antara teoritis dengan tinjauan kasus. Pembahasan dimulai melalui tahapan proses keperawatan yaitu pengkajian, diagnosa keparawatan, perencanaan, pelaksanaan dan evaluasi.

\subsection{Pengkajian}

Pada pembahasan ini diuraikan tentang hasil pelaksanaan tindakan keperawatan dengan pemberian terapi generalis pada klien halusinasi pendengaran. Pembahasan menyangkut analisis hasil penerapan terapi generalis terhadap masalah keperawatan halusinasi pendengaran. Tindakan keperawatan didasarkan pada pengkajian dan diagnosis keperawatan yang terdiri dari tindakan generalis yang dijabarkan sebagai berikut.

Tahap pengkajian pada klien halusinasi dilakukan interaksi perawat-klien melalui komunikasi terapeutik untuk mengumpulkan data dan informasi tentang status kesehatan klien. Pada tahap ini terjadi proses interaksi manusia, komunikasi, transaksi dengan peran yang ada pada perawat sebagaimana konsep tentang manusia yang bisa dipengaruhi dengan adanya proses interpersonal.

Selama pengkajian dilakukan pengumpulan data dari beberapa sumber, yaitu dari pasien dan keluarga pasien. Penulis melakukan pendekatan kepada pasien melalui komunikasi terapeutik yang lebih terbuka membantu pasien untuk memecahkan perasaannya dan juga melakukan observasi kepada pasien. 
Adapun upaya tersebut yaitu:

a. Melakukan pendekatan dan membina hubungan saling percaya diri pada klien agar klien lebih terbuka dan lebih percaya dengan menggunakan perasaan.

b. Mengadakan pengkajian klien dengan wawancara

c. Mengadakan pengkajian dengan cara bertanya kepada keluarga

Dalam pengkajian ini, penulis menemukan kesenjangan karena ditemukan. Pada kasus Tn.P , klien mendengar suara-suara yang menyuruh untuk melakukan tindakan yang tidak baik seperti membanting barang, gelisah, mondar-mandir, tampak tegang, putus asa, sedih dan lain-lain. Gejala gejala yang muncul tersebut tidak semua mencakup dengan yang ada di teori klinis dari halusnasi (Keliat, dkk.2014). Akan tetapi terdapat faktor predisposisi maupun presipitasi yang menyebabkan kekambuhan penyakit yang dialami oleh Tn.P .

Tindakan keperawatan terapi generalis yang dilakukan pada Tn.P adalah strategi pertemuan pertama sampai pertemuan empat. Strategi pertemuan pertama meliputi mengidentifikasi isi, frekuensi, jenis, dan respon klien terhadap halusinasi serta melatih cara menghardik halusinasi. Strategi pertemuan kedua yang dilakukan pada Tn.P meliputi melatih cara mengendalikan dengan bercakap-cakap kepada orang lain. Strategi pertemuan yang ketiga adalah menyusun jadwal kegiatan bersama-sama dengan klien. Strategi pertemuan keempat adalah mengajarkan dan melatih Tn.P cara minum obat yang teratur. 


\subsection{Diagnosa Keperawatan}

Pada Teori Halusinasi (NANDA, 2009-2011), diagnosa keperawatan yang muncul sebanyak 3 diagnosa keperawatan yang meliputi:

1. Harga diri rendah

2. Halusinasi

3. Resiko Perilaku Kekerasan

Sedangkan pada kasus Tn.P ditemukan lima diagnosa keperawatan yang muncul yang meliputi: harga diri rendah, halusinasi, koping individu inefektif, regimen teraupetik inefektif. Dari hal tersebut di atas dapat dilihat terjadi kesamaan antara teori dan kasus. Dimana semua diagnosa pada teori muncul pada kasus Tn.P

\subsection{Implementasi}

Pada tahap implementasi, penulis hanya mengatasi 2 masalah keperawatan yakni: diagnosa keperawatan halusinasi pendengaran dan harga diri rendah. Pada diagnosa keperawatan gangguan persepsi sensori halusinasi pendengaran dilakukan strategi pertemuan yaitu mengidentifikasi isi, frekuensi, waktu terjadi, perasaan, respon halusinasi. Kemudian strategi pertemuan yang dilakukan yaitu latihan mengontrol halusinasi dengan cara menghardik. Strategi pertemuan yang kedua yaitu anjurkan minum obat secara teratur, strategi pertemuan yang ke tiga yaitu latihan dengan cara bercakap-cakap pada saat aktivitas dan latihan strategi pertemuan ke empat yaitu melatih klien melakukan semua jadwal kegiatan.

Pada diagnosa keperawatan harga diri rendah strategi pertemuan yang dilakukan yaitu mengidentifikasi kemampuan dan aspek positif yang masih dimiliki klien. Strategi pertemuan yang kedua yaitu membantu klien menilai kemampuan yang dapat digunakan. Strategi pertemuan yang ketiga yaitu membantu klien memilih/menetapkan kemampuan yang akan dilatih. Strategi pertemuan yang keempat yaitu latih kemampuan yang dipilih klien. 
Untuk melakukan implementsi pada keluarga, pada tahap-tahap diagnosa tidak dapat dilaksanakan karena penulis tidak pernah berjumpa dengan keluarga klien (keluarga tidak pernah berkunjung).

\subsection{Evaluasi}

Pada tinajauan teoritis evaluasi yang diharapkan adalah: Pasien mempercayai perawat sebagai terapis, pasien menyadari bahwa yang dialaminya tidak ada objeknya, dapat mengidentifikaasi halusinasi, dapat mengendalikan halusinasi melalui mengahrdik, latihan bercakap-cakap, melakukan aktivitas serta menggunakan obat secara teratur.

Pada tinjauan kasus evaluasi yang didapatkan adalah: Klien mampu mengontrol dan mengidentifikasi halusinasi, Klien mampu melakukan latihan bercakap-cakap dengan orang lain, Klien mampu melaksanakan jadwal yang telah dibuat bersama, Klien mampu memahami penggunaan obat yang benar: 5 benar. Selain itu, dapat dilihat dari setiap evalusi yang dilakukan pada asuhan keperawatan, dimana terjadi penurunan gejala yang dialami oleh Tn.P dari hari kehari selama proses interaksi. 


\section{BAB V}

PENUTUP

\subsection{Kesimpulan}

Berdasarkan uraian pada pembahasan di atas, maka penulis dapat disimpulkan bahwa:

1. Pengkajian dilakukan secara langsung pada klien dan juga dengan menjadikan status klien sebagai sumber informasi yang dapat mendukung data-data pengkajian. Selama proses pengkajian, perawat mengunakan komunikasi terapeutik serta membina hubungan saling percaya antara perawat-klien. Pada kasus Tn.P , diperoleh bahwa klien mengalami gejalagejala halusinasi seperti mendengar suara-suara, gelisah, sulit tidur, tampak tegang, mondar-mandir,tidak dapat mempertahankan kontak mata, sedih, malu, putus asa, menarik diri, mudah marah dan lain-lain. Faktor predisposisi pada Tn.P yaitu pernah mengalami gangguan jiwa sebelumnya serta memiliki riwayat mengonsumsi alkohol dan obat terlarang.

2. Diagnosa keperawatan yang muncul pada kasus Tn.P ,:Halusinasi pendengaran, isolasi sosial, koping individu inefektif, regimen teraupetik keluarga inefektif, harga diri rendah serta keputusasaan. Tetapi pada pelaksanaannya, penulis fokus pada masalah utama yaitu halusinasi pendengaran.

3. Perencanaan dan implementasi keperawatan disesuaikan dengan strategi pertemuan pada pasien halusinasi pendengaran dan harga diri.

4. Evaluasi diperoleh bahwa terjadi peningkatan kemampuan klien dalam mengendalikan halusinasi yang dialami serta dampak pada penurunan gejala halusinasi pendengaran yang dialami.

\subsection{Saran}

1. Bagi Perawat

Diharapkan dapat menerapkan komunikasi terapeutik dalam pelaksanaan strategi pertemuan 1-4 pada klien dengan halusinasi sehingga dapat mempercepat proses pemulihan klien. 
2. Bagi Institusi Pendidikan

Dapat meningkatkan bimbingan klinik kepada mahasiswa profesi ners sehingga mahasiswa semakin mampu dalam melakukan asuhan keperawatan pada pasien-pasien yang mengalami halusinasi pendengaran

3. Bagi Keluarga pasien

Diharapkan keluaga dapat memberi dukungan yang baik terhadap pasien yang mengalami gangguan jiwa supaya tidak terjadi kekambuhan halusinasi pada pasien 


\section{DAFTAR PUSTAKA}

Aldam, S. F. S., \& Wardani, I. Y. (2019). Efektifitas penerapan standar asuhan keperawatan jiwa generalis pada pasien skizofrenia dalam menurunkan gejala halusinasi. Jurnal Keperawatan Jiwa, 7(2), 165-172. https://doi.org/10.26714/jkj.7.2.2019.167-174

Pardede, J. A, Keliat, B.A \& Wardani, I.Y. (2013). Pengaruh Acceptance And Commitment Therapy Dan Pendidikan Kesehatan Kepatuhan Minum Obat Terhadap Gejala, Kemampuan Berkomitmen Pada Pengobatan Dasar Kepatuhan Pasien Skizofrenia. FIK UI. Depok

Pardede, J. A., Keliat, B. A., \& Yulia, I. (2015). Kepatuhan dan Komitmen Klien Skizofrenia Meningkat Setelah Diberikan Acceptance And Commitment Therapy dan Pendidikan Kesehatan Kepatuhan Minum Obat. Jurnal Keperawatan Indonesia, 18(3), 157-166. 10.7454/jki.v18i3.419

Pardede, J. A., Hamid, A. Y. S., \& Putri, Y. S. E. (2020). Application of Social Skill Training using Hildegard Peplau Theory Approach to Reducing Symptoms and the Capability of Social Isolation Patients. Jurnal Keperawatan, 12(3), 327-340. https://doi.org/10.32583/keperawatan.v12i3.782

Pardede, J. A., Irwan, F., Hulu, E. P., Manalu, L. W., Sitanggang, R., \& Waruwu, J. F. A. P. (2021). Asuhan keperawatan Jiwa Dengan Masalah Halusinasi. https://doi.org/10.31219/osf.io/fdqzn

Pardede, J. A. (2020). Family Knowledge about Hallucination Related to Drinking Medication Adherence on Schizophrenia Patient. Jurnal Penelitian Perawat Profesional, 2(4), 399-408. https://doi.org/10.37287/jppp.v2i4.183

Pardede, J. A. (2020). Family Burden Related to Coping when Treating Hallucination Patients. Jurnal Ilmu Keperawatan Jiwa, 3(4), 453-460. http://dx.doi.org/10.32584/jikj.v3i4.671

Pardede, J. A., \& Siregar, R. A. (2016). Pendidikan Kesehatan Kepatuhan Minum Obat Terhadap Perubahan Gejala Halusinasi Pada Klienskizofrenia. Mental Health, 3(1).

Patricia, H., Rahayuningrum, D. C., \& Nofia, V. R. (2019). Hubungan Beban Keluarga Dengan Kemampuan Caregiver Dalam Merawat Klien 41 Skizofrenia. Jurnal Kesehatan Medika Saintika, 10(2), 45-52.doi: http://dx.doi.org/10.30633/jkms.v10i2.449

Damaiyanti, Iskandar. (2014). Asuhan Keperawatan Jiwa. Bandung: Refika Aditama.

Direja, S. H. Asuhan Keperawatan Jiwa. Yogyakarta: Nuha Medika 
Keliat, Budi dkk. (2019). Asuhan Keperawatan Kesehatan Jiwa. Jakarta: EGC. Mardiah, H., Jatimi, A., Heru, M. J. A., Munir, Z., \& Rahman, H. F. (2020). Pengurangan Stigma Publik Terhadap Peningkatan Quality of Life (QoL) Pasien Skizofrenia. Jurnal Penelitian Kesehatan" SUARA FORIKES"(Journal of Health Research" Forikes Voice"), 11, 23-26. http://dx.doi.org/10.33846/sf11nk404

Keliat B. A, dkk. (2014). Proses Keperawatan Jiwa Edisi II. Jakarta: EGC.

KeliatB. A, Akemat. (2012). Model Praktik Keperawatan Profesional Jiwa. Jakarta: EGC.

Keliat B. A, dkk. (2016). Keperawatan Kesehatan Jiwa Komunitas. Jakarta: EGC

Kemenkes RI. (2013). Riset Kesehatan Dasar; RISKESDAS. Jakarta: Balitbang

Muhith, Abdul. (2011). Pendidikan Keperawatan Jiwa. Yogyakarta : CV Andi OOFSET.

Nyumirah, S. (2013). Peningkatan kemampuan interaksi sosial (kognitif, afektif dan perilaku) melalui penerapan terapi perilaku kognitif di rsj dr amino gondohutomo semarang. Jurnal keperawatan jiwa, 1(2). https://doi.org/10.26714/jkj.1.2.2013.\%25p

Prabowo, E. (2014). Konsep \& Aplikasi Asuhan Keperawatan Jiwa. Yogyakarta: Nuha Medika

Prabowo, E. (2014). Buku Ajar Keperawatan Jiwa. Yogyakarta: Nuha Medika.

Stuart, G. W., Keliat, B. A., \& Pasaribu, J. (2016). Prinsip dan praktik keperawatan kesehatan jiwa stuart. Edisi Indonesia. Singapore: Elsevier

Stuart, G.W., \& Laraia, M.T. (2005). Principle and practice of psyciatric nursin9 th ed. St Louis : Mosby year book

Stuart, G. W. (2009). Buku Saku Keperawatan Jiwa. Edisi 5. Jakarta. EGC.

Fadhillah H. (2017). Standar Diagnosis Keperawatan Indonesia. Jakarta Selatan: DPP, PPNI

Fadhillah H. (2018). Standar Intervensi Keperawatan Indonesia. Jakarta Selatan: DPP, PPNI 